\title{
REINTERPRETASI RIQAB SEBAGAI KORBAN EKSPLOITASI SEKSUAL DALAM HUKUM ZAKAT
}

\author{
Zainuddin*, Sahban \\ Fakultas Hukum Universitas Muslim Indonesia Makassar \\ J1. Urip Sumohardjo KM. 05, Makassar, Sulawesi Selatan, 90231 \\ zainuddin.zainuddin@umi.ac.id
}

\begin{abstract}
In al-Qur' an, there are eight groups that are entitled to receive zakat, one of which is riqab is interpreted as a slave. For the current context, riqab no longer needs to be understood textually as a slave but riqab needs to be interpreted contextually ie economically exploited people. Victims of sexual exploitation can be categorized as riqab who are entitled to receive zakat. Victims of sexual exploitation are people who are unable to free themselves from slavery because in general they have a low educational background and are economically weak. Zakat can be distributed equally among the eight groups so that zakat can prosper the people and the realization of socio-economic justice. Therefore, the need for zakat management institutions and the government to contextually understand riqab so that zakat can alleviate poverty and prevent sexual exploitation which is a crime against human rights.
\end{abstract}

Keywords: Riqab; Victims; Sexual Exploitation; Zakat Law.

\begin{abstract}
Abstrak
Dalam al-Qur'an ada delapan kelompok yang berhak menerima zakat salah satunya adalah riqab diartikan sebagai budak. Untuk konteks sekarang, riqab tidak perlu lagi dipahami secara tekstual sebagai budak akan tetapi riqab perlu dimaknai secara kontekstual yaitu orang-orang yang tereksploitasi secara ekonomi. Korban eksploitasi seksual dapat dikategorikan sebagai riqab yang berhak menerima zakat. Korban eksploitasi seksual ini adalah orang yang tidak mampu membebaskan dirinya dari perbudakan karena pada umumnya berlatar belakang pendidikan yang rendah dan berekonomi lemah. Zakat dapat didistribusikan secara merata ke delapan kelompok tersebut, sehingga dapat menyejahterakan umat dan terwujudnya keadilan sosial ekonomi. Oleh karena itu, perlunya lembaga pengelola zakat dan pemerintah untuk memahami secara kontekstual riqab sehingga zakat mampu mengentaskan kemiskinan dan mencegah terjadinya eksploitasi seksual yang merupakan kejahatan terhadap hak asasi manusia.
\end{abstract}

Kata Kunci: Riqab; Korban; Eksploitasi Seksual; Hukum Zakat.

\section{A. Pendahuluan}

Zakat merupakan salah satu instrumen ekonomi umat yang berfungsi untuk menyejahterakan umat Islam. Zakat khususnya zakat mal diperintahkan kepada orang-orang yang mampu secara ekonomi. Oleh karena itu, zakat itu dalam hierarki rukun Islam ditempatkan pada urutan ketiga sesudah syahadat dan salat, di mana zakat lebih berorientasi pada ekonomi yang bersentuhan dengan harta benda artinya orang yang sanggup secara ekonomi yang diwajibkan untuk menunaikan zakat.

Zakat adalah ibadah yang memiliki dua dimensi, yaitu vertikal (langsung kepada Allah) dan horizontal (interaksi dengan sesama manusia). Zakat merupakan ibadah sebagai bentuk ketaatan kepada Allah dan sebagai kewajiban kepada sesama manusia. 
Zakat juga sering disebut ibadah kesungguhan dalam harta. Tingkat pentingnya zakat terlihat dari banyaknya ayat yang menyandingkan perintah zakat dengan perintah shalat (Malahayatie, 2016).

Diwajibkannya zakat dalam Islam memiliki implikasi makna yang fundamental, zakat selain berkaitan erat dengan aspek-aspek ketuhanan, juga berkaitan erat dengan masalah ekonomi dan sosial. Terkait dengan aspek ketuhanan (hablunminallah) beberapa ayat al-Quran yang menegaskan masalah zakat, di antaranya ada 27 ayat yang menyandingkan kewajiban zakat dengan kewajiban shalat secara bersamaan (Bahri S, 2016).

Di Indonesia, pengelolaan zakat secara formal diatur dalam Undang-Undang No. 38 Tahun 1999 tentang Pengelolaan Zakat, kemudian direvisi menjadi Undang-Undang Nomor 23 Tahun 2011 tentang Pengelolaan Zakat. Menurut Undang-Undang tersebut terdapat dua lembaga/badan yang berhak mengelola zakat, yaitu Badan Amil Zakat yang dikelola pemerintah dan Lembaga Amil Zakat yang dikelola masyarakat.

Tujuan pengelolaan zakat secara formal adalah untuk: (1) meningkatkan efektifitas dan efisiensi pelayanan dalam pengelolaan zakat, (2) meningkatkan manfaat zakat untuk mewujudkan kesejahteraan masyarakat dan penanggulangan kemiskinan. Apabila ditelaah secara positif tujuan tersebut mengandung makna bahwa mengingat potensi zakat yang begitu besar maka perlu upaya secara kelembagaan agar pelayanan zakat berjalan efektif (tepat sasaran), serta dapat mendayagunakan untuk mendukung program-program pemberian jaminan perlindungan sosial dan peningkatan kesejahteraan umat. Adapun ruang lingkup pengelolaan zakat menurut Undang-Undang Nomor 23 Tahun 2011 meliputi kegiatan perencanaan, pelaksanaan, dan pengordinasian dalam pengumpulan, pendistribusian, dan pendayagunaan zakat (Fitri, 2017).

Komnas Perempuan memetakan jenisjenis kekerasan seksual yang dilaporkan oleh korban yakni pelecehan seksual, eksploitasi seksual, pemaksaan penggunaan kontrasepsi, pemaksaan melakukan aborsi, perkosaan, pemaksaan perkawinan, pemaksaan pelacuran, perbudakan seksual, dan penyiksaan seksual. Berdasarkan pengaduan korban, banyak kasus yang terjadi di luar nalar kemanusiaan juga, misalnya tentang penelanjangan perempuan di bandara atas nama keamanan dan ancaman mengedarkan video porno (revenge porn) (Aprilia, 2018).

Berdasarkan Catatan Tahunan 2019, Komisi Perlindungan Perempuan bahwa sebanyak 14 kasus perbudakan seksual, dan 200 kasus eksploitasi seksual yang terjadi di Indonesia. Pada dasarnya eksploitasi seksual mengandung unsur adanya hubungan seksual atau pemanfaatan tubuh dengan pelaku/orang lain yang semata-mata untuk kepentingan pelaku. Eksploitasi seksual sebagai jenis kekerasan seksual belum dikenal dalam KUHP ataupun undangundang yang sifatnya lex specialis lainnya sehingga seringkali kasus-kasus jarang yang diproses melalui jalur hukum (Aryani \& et.al., 2019)

Instrumen dalam Islam yang berhubungan peningkatan kualitas kemanusiaan dengan mencegah terjadinya eksploitasi manusia atas manusia (pembebasan manusia dari ketertindasan ekonomi) harta adalah zakat. Pada dasarnya, zakat merupakan pranata keagamaan yang berfungsi untuk mewujudkan keadilan sosial bagi seluruh umat manusia dengan memperhatikan dan meningkatkan kepedulian terhadap masyarakat yang kurang mampu. Zakat merupakan instrumen ekonomi yang diperuntukkan sebagai pengurang kesenjangan ekonomi yang terjadi di masyarakat. Secara khusus zakat dalam pendistribusiannya diutamakan kepada orang yang serba kekurangan di dalam harta. Tujuan utama dari ajaran Islam tersebut adalah memelihara dan melindungi agama, jiwa, akal, keturunan dan harta benda (Zainuddin, 2017). Apabila zakat terkelola dengan baik, maka permasalahan kesejahteraan dan keadilan sosial dapat teratasi (Zainuddin, 2013). 
Dalam Islam ada delapan kelompok yang berhak menerima zakat, secara garis besar dikategorikan dalam dua kelompok besar, yaitu: Pertama, kelompok penerima zakat yang dasarkan pada kebutuhan, seperti kelompok fakir, miskin, budak, pengutang, orang yang dalam perjalanan. Kelompok ini berhak atas zakat untuk memenuhi kebutuhan hidupnya sebagai orang miskin dan berkebutuhan, untuk membebaskan diri dari perbudakan dan pengutangan atau dalam situasi terpaksa melakukan perjalanan. Kedua, kelompok yang berhak atas zakat bukan didasarkan pada pemenuhan kebutuhannya, seperti Amil, muallaf dan fisabilillah. Amil diperlukan untuk memfasilitasi pengelolaan pembayaran zakat dan pendistribusiannya. Muallaf diperlukan untuk menarik lebih banyak orang untuk masuk Islam atau sebagai dukungan finansial ketika mereka baru dalam Islam. Sementara fisabilillah yang diperlukan untuk menegakkan Islam dan menyebarkan dakwah (Khairuldin, 2013).

Dalam perkembangannya, konsep mustahik serta aplikasinya pada saat ini perlu dicermati karena kondisi yang berkembang terkait dengan perubahan zaman, sehingga perlu adanya upaya penggalian hukum untuk menyikapi perkembangan zaman agar hukum Islam tetap dapat beradaptasi dengan waktu dan tempat. Hal ini menyebabkan kelangsungan mustahik dalam dataran aplikatif sering kali tidak menentu. Apalagi konteks zakat sendiri selama ini tidak lebih diproyeksikan sebagai lembaga karitas, yakni sebuah hubungan belas kasihan antara si kaya dengan si miskin (Abdurrahman, 1995). Oleh karena itu tulisan ini memfokuskan kepada pentingnya pemaknaan ulang asnaf $a r-r i q a b$ secara kontekstual agar pemberian zakat terdistribusi secara merata ke delapan kelompok penerima zakat sehingga terwujud keadilan sosial ekonomi dalam pengelolaan zakat. Ruang lingkup ini menunjukkan kebaruan artikel ini dibandingkan dengan karya ilmiah yang pernah ada sebelumnya.
Pada penulisan artikel ini, ada dua rumusan masalah yang penulis telaah dalam pembahasan, yaitu: Pertama, bagaimanakah sisi gelap perempuan korban perdagangan manusia? Kedua, bagaimanakah pemaknaan riqab dalam konteks ekploitasi seks komersial?

\section{B. Pembahasan}

\section{Sisi Gelap Perempuan Korban Perdagangan Manusia}

Maraknya perdagangan perempuan untuk dijadikan Pekerja Seks Komersial (PSK) menjadi penanda rentannya perempuan sebagai objek eksploitasi seks komersial. Perdagangan perempuan dan anak perempuan untuk eksploitasi seksual tetap menjadi masalah serius di sebagian besar negara di Asia khususnya Asia Tenggara. Berdasarkan Laporan PBB untuk Narkoba dan Kejahatan atau United Nations Office on Drugs and Crime (UNODC) Tahun 2019, perdagangan manusia untuk eksploitasi seksual menyumbang sekitar 79 persen dari jumlah total kasus di Thailand dari 2014 hingga 2017, terutama melibatkan korban perempuan dari wilayah Mekong, tetapi juga dari beberapa negara di Afrika, Timur Tengah, dan Asia Tengah, seperti serta Rusia dan Sri Lanka. Dari total jumlah korban yang diperdagangkan untuk eksploitasi seksual, hampir 70 persen adalah perempuan di bawah umur. Sebagian besar kasus perdagangan yang dilaporkan di Malaysia dalam beberapa tahun terakhir juga terkait dengan eksploitasi seksual, yang menyumbang sekitar 60 hingga 73 persen dari 2016 hingga 2018, dengan sebagian besar korban adalah perempuan dan anak perempuan. Di Myanmar, jumlah perempuan yang diperdagangkan dengan tujuan eksploitasi seksual meningkat lebih dari dua kali lipat dari tahun 2013 hingga 2017. Selain itu, perempuan Asia Tenggara yang diperdagangkan di luar kawasan untuk eksploitasi seksual telah menjadi masalah yang terus-menerus, terutama di Jepang dan Republik Korea, tetapi juga di beberapa 
negara di Eropa dan Timur Tengah (United Nations Office on Drugs and Crime, 2019).

Korban perdagangan orang pada umumnya dijual dan dipekerjakan sebagai pembantu rumah tangga, pemandu karaoke, pelayan restoran, dan prostitusi. Meskipun setiap orang berpotensi menjadi korban dan umumnya adalah mereka yang dari ekonomi lemah serta berpendidikan rendah, dari pedesaan yang tak tahu menahu dunia luas (Irianto, 2008).

Menjadi PSK merupakan bentuk kekerasan terhadap perempuan yang diselenggarakan oleh suatu mekanisme ekonomi yang merugikan perempuan. Ada standar ganda yang diterapkan negara, di satu sisi ada tindakan represif yang dilakukan oleh negara terhadap PSK tetapi di sisi lain ada beban kewajiban yang harus ditunaikan kepada negara dalam bentuk pajak. Sementara masyarakat menganggap bahwa menjadi PSK adalah pekerjaan rendah dan hina akan tetapi tempat-tempat prostitusi tidak pernah sepi dari pengunjung.

Perempuan kerapkali terpaksa dan dipaksa masuk ke dalam prostitusi oleh suatu jaringan sindikat perdagangan perempuan dengan menggunakan beragam sarana, yang berkisar dari sekadar janji-janji muluk pekerjaan, perkawinan atau perbudakan terselubung dari cinta, loyalitas terhadap mucikari, sampai ke penculikan fisik dan penyekapan. Jadi yang sangat esensial menjadi faktor pendorong terjadinya perdagangan perempuan untuk menjadi PSK adalah sistem rekrutmen yang menggunakan unsur penipuan, bujukan, hingga ke tindak pemaksaan dan kekerasan (Suryandaru, 2001). Beberapa jenis ekploitasi seks komersial adalah eksploitasi seks komersial yang terorganisir oleh mucikari, eksploitasi perempuan oleh rentenir, eksploitasi ekonomi perempuan oleh pasangan hidup, eksploitasi ekonomi perempuan oleh keluarga, eksploitasi perempuan pada tubuh (Chusaini, 2019).

Korban perdagangan orang yang dipekerjakan sebagai PSK, tentunya tidak sesuai dengan ajaran Islam dan nilai-nilai Pancasila, khususnya sila Kemanusiaan yang
Adil dan Beradab dan sila Keadilan Sosial Bagi Seluruh Rakyat Indonesia. Kemanusiaan yang adil dan beradab merupakan dasar dari perlindungan hak asasi yaitu memanusiakan manusia secara beradab tanpa mengurangi haknya sedikitpun. Sedangkan keadilan sosial merupakan keadilan yang digunakan untuk membedakan keadilan sosial dengan konsep keadilan dalam hukum (Febriansyah, 2017).

Dalam sila kedua dan sila kelima tersebut tertuang nilai-nilai tujuan negara untuk menciptakan keadilan dalam konteks kehidupan bersama. Makna dari sila kedua dan sila kelima mengandung makna keadilan yang berupa nilai, tentunya harus diwujudkan dalam kehidupan bersama. Keadilan tersebut didasari dan dijiwai oleh hakikat keadilan sosial yaitu keadilan dalam hubungan manusia dengan dirinya sendiri, hubungan manusia dengan sesama, hubungan manusia dengan bangsa dan negaranya, kemudian yang terakhir adalah hubungan manusia dengan Tuhannya (Febriansyah, 2017).

Ada beberapa faktor yang melatarbelakangi seorang perempuan menjadi pekerja seks komersial yaitu adanya kesulitan untuk memenuhi kebutuhan ekonomi baik dirinya maupun keluarganya, faktor keterampilan yang tidak dimiliki oleh perempuan rendahnya pendidikan yang dimiliki oleh korban, gaya hidup yang hedonis sebagai bagian dari faktor ekonomi. Adapun faktor yang kedua menjadi korban penipuan yang berkedok menawarkan suatu pekerjaan tetapi dipekerjakan menjadi pekerja sektor komersial. Faktor yang terakhir adalah adanya kekerasan seksual seseorang yang pernah menjadi korban kekerasan seksual sebelumnya (Yuniantoro, 2018).

\section{Pemaknaan Riqab dalam Konteks Ekploitasi Seks Komersial}

Pekerja Seks Komersial (PSK) yang dieksploitasi oleh mucikarinya pada dasarnya dapat dipersamakan dengan budak untuk konteks sekarang yang disebut dalam terminologi hukum zakat. Riqab berasal dari 
bahasa Arab dari kata raqaba yang berarti tengkuk tetapi secara terminologi riqab itu bermakna budak hamba sahaya adalah hamba sahaya yang dimiliki seseorang agar menjadi merdeka (Malahayatie, 2016). Kata Riqab dalam al-Qur'an diulang dalam tiga kali yaitu pada Q.S. Al-Baqarah ayat 177, Q.S. Taubah ayat 60 dan Q.S. Muhammad ayat 4. Lafadz riqab dalam al-Qur'an menurut al-Ragib al-Asfahani memiliki makna budak mukattab yang dibebaskan melalui harta zakat (Al-Ashfahani, 1992)

Dari Q.S. at-Taubah Ayat 60 di atas klasifikasinya sudah jelas, hanya golongan "fi ar-riqab" yang dianggap kurang jelas dan kurang tegas. Bukan karena lafadznya tetapi karena pelaksanaannya pada zaman Rasulullah yang digunakan untuk memerdekakan budak mukattab yang telah dijanjikan oleh tuannya akan dilepaskan jika ia dapat membayar sejumlah tertentu dan termasuk pula budak yang belum dijanjikan untuk dimerdekakan (Ash-Shiddieqy, 1997). Dinamakan riqab adalah budak yang belum merdeka diberi dana zakat untuk memerdekakan dirinya dari majikannya dengan zakat kemudian dibebaskan. Dalam hal ini tidak dipandang bagaimana caranya, tetapi yang lebih penting adalah fungsi dari dana zakat tersebut (al-Zuhaili, 2009).

Menurut M. Quraish Shihab, bahkan boleh jadi kita dapat berkata bahwa tenaga kerja yang diikat kontrak dengan satu pengusaha, yang dengan alasan-alasan yang dapat dibenarkan harus membatalkan kontraknya secara sepihak, sedangkan pemilik perusahaan enggan membatalkan kecuali dengan ganti rugi, dapat juga mendapat bantuan zakat, dengan mengambil bagian dari $f i$ ar-riqab atau al gharimin (Shihab, 2002).

Ulama Selangor, Malaysia, juga menganologikan (qiyas) korban perdagangan orang sebagai penerima zakat yang masuk kategori riqab yang sehingga dapat membebaskan diri dari perbudakan modern. Maka, lembaga-lembaga zakat di Selangor, Malaysia, seperti Lembaga Zakat Selangor, memberikan perhatian khusus terhadap mustahik ini. Tidak sedikit pelacur dan anak-anak jalanan yang terbebas dari perdagangan orang dan mendapatkan kehidupan yang layak dari zakat para muzaki yang disalurkan melalui Lembaga Zakat Selangor (Ash-Shiddieqy, 1997). Di negaranegara di Malaysia yang menggunakan interpretasi Islam kontemporer memandang penerima riqab masih dikaitkan dengan jenis perbudakan, termasuk mereka yang berjuang untuk membebaskan diri dari kebodohan dan dosa (PSK) (Wan Mohd Khairul Firdaus \& Mahadi, 2013). Riqab itu adalah melepaskan seseorang dari perbudakan untuk konteks sekarang perbudakan dalam bentuk lain seperti eksploitasi seks promosi eksploitasi seksual pada perempuan ini merupakan salah satu bentuk perbudakan modern

Seseorang dapat dikatakan riqab apabila kebebasannya terbelenggu oleh seseorang yang lainnya. Jika dengan perjanjian bahwa "majikan" akan membebaskan riqab itu dengan syarat harus menebusnya baik uang atau harta dengan jumlah tertentu, maka dapat digunakan harta zakat untuk membebaskan mereka, apalagi jika dilihat ada kebaikan pada korban eksploitasi seks komersial tersebut jika telah dimerdekakan.

Ar-Riqab merupakan salah satu mustahik zakat yang perlu pengkontekstualisasian makna agar spirit zakat sebagai intrumen penyejahteraan umat dapat tercapai. Jika dewasa ini tidak terlihat lagi model perbudakan sebagaimana pada masa Islam belum datang, tidak berarti bahwa ayat-ayat perbudakan tidak relevan untuk diwacanakan. Fakta tentang terjadinya perdagangan orang yang menimpa kelompok marginal patut untuk dikritisi perspektif doktrin agama karena fenomena ini sarat dengan tindakan yang tidak berperikemanusiaan (Ash-Shiddieqy, 1997).

Substansi dari ar-riqab sebenarnya adanya usaha dalam membebaskan orang atau sekelompok orang dalam keadaan teraniaya dan ketidakadilan. Saat ini hampir dipastikan karena tidak relevannya definisi $a r-r i q a b$ dalam konteks fikih klasik secara tidak langsung menghilangkan definisi ini di berbagai lembaga zakat Indonesia. Ketika berbicara asnaf zakat, dapat dipastikan ar- 
riqab adalah asnaf yang hilang dari zakat (Ash-Shiddieqy, 1997).

Riqab adalah untuk membebaskan eksploitasi atau pemerasan oleh manusia atas manusia yang harus dibebaskan, baik manusia sebagai individu maupun manusia sebagai komunal. Berdasarkan alasan hukum ini, maka kebijaksanaan pendayagunaan zakat untuk jatah riqab dapat diarahkan antara lain sebagai berikut adalah: 1) untuk menebus orang-orang Islam yang ditawan oleh manusia; 2) untuk membantu negara Islam atau negara yang sebagian besar penduduknya beragama Islam yang sedang berusaha untuk melepaskan diri dari belenggu perbudakan modern kaum penjajah modern; 3) pembebasan budak temporer dari eksploitasi pihak lain, misalnya pekerja kontrak dan ikatan kerja yang tidak wajar; 4) menurut tim peneliti dan seminar zakat DKI Jakarta, jatah riqab dapat berupa dana untuk membantu membebaskan pedagang, pengusaha, petani, nelayan kecil dan sebagainya dari tekanan lintah darat dan pengijon (Permono, 1993).

\section{Simpulan}

Zakat merupakan salah satu instrumen dalam Islam yang lebih menekankan pada dimensi ekonomi untuk mewujudkan keadilan sosial ekonomi umat Islam. Dalam al-Qur'an, zakat tidak bisa dipisahkan dengan shalat karena dua hal yang saling berkaitan. Shalat merupakan simbolisasi hubungan manusia dengan Tuhan, sedang zakat merupakan simbolisasi hubungan manusia dengan sesama manusia. Dalam alQur'an ada delapan kelompok yang berhak menerima zakat, salah satunya adalah riqab yang secara sederhana diartikan sebagai budak seperti arti yang dipahami oleh ulama-ulama terdahulu. Riqab ini dalam konteks sekarang tidak boleh lagi dipahami secara tekstual sebagai budak akan tetapi riqab perlu dimaknai secara kontekstual yaitu orang-orang yang tereksploitasi secara ekonomi. Korban eksploitasi seksual dapat dikategorikan sebagai riqab yang berhak menerima zakat karena pada umumnya korban eksploitasi seksual ini orang yang tidak mampu membebaskan dirinya dari belenggu mucikari dan pada umumnya juga korban eksploitasi seksual Ini berlatar belakang pendidikan yang rendah dan berekonomi lemah. Adanya pemahaman kontekstual ini, maka zakat dapat didistribusikan secara merata ke delapan kelompok tersebut, sehingga zakat dapat menyejahterakan umat dan terwujudnya keadilan sosial ekonomi. Oleh karena itu, perlunya lembaga pengelola zakat dan pemerintah untuk memahami secara kontekstual riqab sebagai korban eksploitasi seksual sehingga berimplikasi pada pengelolaan zakat yang mampu mengentaskan kemiskinan dengan mencegah terjadinya terjadinya eksploitasi seksual yang merupakan kejahatan terhadap hak asasi manusia.

\section{DAFTAR PUSTAKA}

Abdurrahman, M. (1995). Islam Transformatif. Jakarta: Pustaka Firdaus.

Al-Ashfahani, R. (1992). Mufradat Al Fazh Al-Qur `an. Riyadh: r Al-Syamsiyah.

al-Zuhaili, W. (2009). Tafsir Al-Munir Fi 'Aqidah Wasy-Syari'ah wal Manhaj-. Beirut, Lebanon: Dar el-Fikr.

Aprilia, I. R. (2018). Reconstructing the Notion of Nationalism: Conversations About Women and Nationalism. Jurnal Perempuan, 23(3).

Aryani, A. V., \& et.al. (2019). Korban Bersuara, Data Bicara Sahkan RUU Penghapusan Kekerasan Seksual Sebagai Wujud Komitmen Negara. Jakarta.

Ash-Shiddieqy, T. M. H. (1997). Pedoman Zakat. Semarang: Pustaka Rizki Putra.

Bahri S, A. (2016). Zakat Sebagai Instrumen Pembangunan Ekonomi Kesejahteraan Ummat. Li Falah: Jurnal Studi Ekonomi Dan Bisnis Islam, I(2), 74-89.

Chusaini, I. (2019). Korban Eksploitasi Ekonomi Perempuan Pekerja Seks 
Komersial di Rawa Bebek Penjaringan Jakarta Utara. Universitas Islam Negeri Syarif Hidayatullah.

Febriansyah, F. I. (2017). Keadilan Berdasarkan Pancasila Sebagai Dasar Filosofis Dan Ideologis Bangsa. DiH: Jurnal Ilmu Hukum, 13(25), 1-27. http://doi.org/10.30996/dih.v13i25.1545

Fitri, M. (2017). Pengelolaan Zakat Produktif sebagai Instrumen Peningkatan Kesejahteraan Umat. Economica: Jurnal Ekonomi Islam, $8(1)$ 149. http://doi.org/10.21580/economica.2017 .8.1.1830

Irianto, S. (ed. . (2008). Perempuan dan Hukum: Menuju Hukum yang Berperspektif Kesetaraan dan Keadilan. Jakarta: Yayasan Obor Indonesia.

Khairuldin, W. M. K. F. W. (2013). The Philosophy and Elasticity of Zakah Distribution in Islam. International Journal of Education and Research (Vol. 1).

Malahayatie, M. (2016). Interpretasi Asnaf Zakat Dalam Konteks Fiqih Kontemporer (Studi Analisis Fungsi Zakat Dalam Pemberdayaan Ekonomi Umat). Jurnal Al Mabhats, 1(1), 48-72.

Permono, S. H. (1993). Pendayagunaan Zakat dalam Rangka Pembangunan Nasional. Jakarta: Pustaka Firdaus.

Shihab, M. Q. (2002). Tafsir Al-Misbah,
Pesan, Kesan dan Keserasian al Quran. Jakarta: Lentera Hati.

Suryandaru, Y. S. (2001). Hegemoni dan Reproduksi Kekuasaan Dalam Perdagangan Perempuan (Trafficking) Untuk Prostitusi. Manusia, Kebudayaan, Dan Politik, XIV(2), 3550.

United Nations Office on Drugs and Crime. (2019). Transnational Organized Crime in Southeast Asia: Evolution, Growth and Impact. http://doi.org/10.4324/978020314602621

Wan Mohd Khairul Firdaus, W. K., \& Mahadi, M. (2013). The philosophy and elasticity of zakah distribution in Islam. International Journal of Education and Research, 1(8), 1-12.

Yuniantoro, F. (2018). Eksploitasi Seksual Sebagai Bentuk Kejahatan Kesusilaan dalam Peraturan Perundang-undangan. JUSTITIA JURNAL HUKUM, 2(1), 105-125.

Zainuddin, Z. (2013). Hukum Zakat: Perspektif Normatif, Kesejahteraan dan Keadilan Sosial. Makassar: Alauddin University Press.

Zainuddin, Z. (2017). Restorative Justice Concept on Jarimah Qishas in Islamic Criminal Law. Jurnal Dinamika Hukum, $\quad$ 17(3), 335. http://doi.org/10.20884/1.jdh.2017.17.3. 826 